To date the Consortium has concentrated its efforts on public domain American law materials. It offers a wide range of titles in the following areas: Virtually all of the reports and decisions of the various U.S. Federal Administrative Agencies, most of the official reports of the various U.S. federal courts, U.S. Congressional materials, including the Statutes at Large and the various editions of the U.S. Code, a wide range of international law materials, including the major treaty series published by the U.S. Department of State, as well as the U.N. and League of Nations treaty series, the official reports of the courts of some eighteen U.S. states, the full list of all discontinued court reports for New York, all primary legal materials for the states of Michigan and Hawaii, many early American annotated court reports series, and a basic Native American legal materials collection numbering some 1,000 volumes.

Materials are uniformly provided in the same format selected by the U.S. Government Printing Office, namely 24X Diazo film, with a negative image, a maximum of 98 pages per fiche and with eye-visible headers. All titles are sold complete. Libraries may become participants by ordering one or more titles. Inquiries for more information should be addressed to: LLMC, P.O. Box 11033, Honolulu, Hawaii 96828.

JERRY DuPONT

University of Hawaii

\title{
LIBRARIES OF LAW FIRMS AND CORPORATE LEGAL DEPARTMENTS IN THE UNITED STATES
}

The findings of recent survey, conducted by the Legal Times of Washington (one of the United States legal newspapers with a national circulation), indicates that a large proportion of the major law firms in this country spend between US $\$ 100,000$ and US $\$ 200,000$ annually on their libraries. A majority of large corporations spend between US $\$ 50,000$ and US $\$ 100,000$ on the libraries of their law department. Nevertheless, the Legal Times of Washington concludes (in its issue of June 23, 1980) that "the nation's premier law firms and corporate law departments still allocate an extremely small portion of their resources to the law library and legal research".

The survey was conducted among the countries 50 largest law firms and 25 largest corporate law departments (as well as 10 biggest law firms in Washington, D.C.).

The same issue of the newspaper contains an article on the role of librarians and information specialists in law firms, and another article, authored by George S. Grossman of Northwestern University Law Library in Chicago, on cataloging of law books by computer. 